\title{
PROTECTION OF THE RIGHTS OF CHILDREN AND MINORS IN THEIR TRANSACTIONS IN THE INFORMATION SOCIETY
}

PROTECCIÓN DE LOS DERECHOS DE LOS NIÑOS Y MENORES EN SUS TRANSACCIONES EN EL SOCIEDAD DE LA INFORMACIÓN

\author{
Oleksandr Omelchuk ${ }^{*}$ \\ Olena Cherniak ${ }^{* *}$ \\ Nataliia Tyshcuk ${ }^{* * *}$
}

\begin{abstract}
The article is devoted to the analysis of features that arise when committing transactions by children and minors in the development of information society, identifying problems that arise when committing such transactions out of their legal capacity, as well as to the issue of the protection of violated rights and legitimate interests of children and minors due to the pandemic. The dialectical method of cognition, the method of system-structural analysis, he formal-logical method, the comparative-legal method, the method of logical analysis and dogmatic interpretation of legal norms were used preparing the article. The structure of the body of the text is comprised of such sections as introduction, methodology, analysis of recent research, results and discussion, conclusions. The main conclusion of the study is the establishing the need to clarify the amount of legal capacity of children and minors in different age groups. It is proposed to consolidate
\end{abstract}

\footnotetext{
* Ph. D., Associate Professor of Civil law Department of National University "Odesa Law Academy”, Odesa (Ukraine). ORCID 0000-0002-0082-3619. olekomel@ gmail.com

** Ph.D., Associate Professor, Head of Department of International and European law Leonid Yuzkov, Khmelnytskyi University of Management and Law, Khmelnytsk (Ukraine). ORCID 0000-0001-5104-6648. chernyack.lena@gmail.com

*** Ph.D. candidate, Civil Law Department of National University “Odesa Law Academy”, Odesa (Ukraine). ORCID 0000-0002-6068-9263. natsivn0704@gmail.com
} 
the division of minors into the following groups: from birth to 6 years; from 6 to 10 years; and from 10 to 14 years.

Keywords: Transactions, Child, Minor, Legal Personality, Information Society

Resumen: El artículo analiza las características que surgen cuando se producen transacciones de niños y menores en el desarrollo de la sociedad de la información, identificando los problemas que surgen al realizarlas sin que tengan suficiente capacidad jurídica, así como al tema de la protección de los derechos e intereses legítimos de los niños y menores puestos en riesgo debido a la pandemia. En la preparación del artículo se utilizaron el método dialéctico de la cognición, el método de análisis sistémicoestructural, el método formal-lógico, el método comparativo-jurídico, el método de análisis lógico y la interpretación dogmática de las normas jurídicas. La estructura del análisis comienza con una introducción y la explicación de la metodología, para luego abordar el análisis de investigaciones recientes, los resultados y discusión del estudio, para finalizar con las conclusiones. En la conclusión se establece la necesidad de esclarecer la capacidad jurídica que debe otorgársele a los niños y menores, según su edad. Se propone consolidar la división de los menores en los siguientes grupos: desde el nacimiento hasta los 6 años; de 6 a 10 años; y de 10 a 14 años.

Palabras clave: Transacciones, niño, menor, personalidad jurídica, sociedad de la información

Summary. I. Introduction. II. Methodology. III. Analysis of recent research. IV. Results and discussion V. Conclusions. References.

\section{INTRODUCTION}

With the rapid spread of a new respiratory disease, the outbreak of which was declared a pandemic by the World Health Organization on March 11, 2020, many countries are taking steps to prevent the spread of the disease. Ukraine is no exception from this list.

Following the Resolution $\mathrm{n}^{\circ} 211$ of the Cabinet of Ministers of Ukraine, "On prevention of the spread of acute respiratory disease Covid-19 caused by coronavirus SARS-CoV 2" (March 11, 2020), several quarantine measures were taken. This Resolution has already been amended six times. 
On April 2, 2020, persons under the age of 14 were prohibited from staying in public places unaccompanied by parents, adoptive parents, guardians, trustees, foster parents, and other persons under the law or adult relatives of the child.

The transition into the online mode of all spheres of our lives, including transactions, awareness of children and minors in the use of technology and the mass transition to online shopping, non-cash forms of payment, the introduction of various services, which serve this area, raises the question of the ratio of the expansion of the actual opportunities of children and minors to perform transactions and their performance within the legal norms, as well as the protection of these persons from illegal or unprofitable transactions under the influence of traditional factors (error, deception, abuse, etc.) and special factors that are directly related to the use of technology (electronic transaction, identification, and confirmation of capacity, etc.).

Given that the parties to civil relations are the bearers of relevant rights and responsibilities, the persons should have the opportunity to be a party to any civil legal relationship, namely, have the necessary volume of legal capacity. One of the elements of legal personality is the commission of a transaction because, according to the law, persons of "any" age can commit transactions per the volume of their legal capacity. Given that the range of transactions that children and minors can commit (according to the law) within their capacity does not correspond to the real range of capabilities of these persons. The range is much wider. It is necessary, through the category of legal capacity, to determine the range of transactions that children and minors can commit in the context of informatization of society, quarantine restrictions, as well as to clarify the age limits for such transactions and to provide the necessary level of protection of the rights and legitimate interests of children and minors.

The purpose of the article is to analyze the features that arise in the commission of transactions by children and minors in the development of information technology and quarantine restrictions, identify problems that arise in the assignment of such transactions outside their capacity, resolving the issue of the protection of violated rights and legitimate interests of children and minors.

\section{MeThOdOLOGY}

The dialectical method of cognition allowed to identify and investigate the features of transactions committed by children and minors in the 
information society, in particular, when utilizing the internet, as well as problems of application of civil legal consequences of the commission of such transactions.

Applying the method of system-structural analysis the following notions were considered, as the concept and essence of transactions committed by children and minors in the context of the formation and development of the information society and the quarantine restrictions, features of the modern understanding of transactions committed on web sites, social networks, computer games, etc.; problems of the actual expansion of the capacity of children and minors in transactions; features of ensuring the protection of the rights of children and minors when conducting transactions through the use of the latest information technologies.

Moreover the formal-logical method was used to analyze the conceptual apparatus and content of current legislation that regulates the relations that arise when committing transactions by children and minors. The comparative-legal method allowed to correlate national and international legislation on the protection of children's rights from information that harms their health, development, and guarantee of the fundamental rights of the child, in particular, when they commit transactions. The method of logical analysis and dogmatic interpretation of legal norms was used in formulating conclusions and proposals.

\section{ANALYSIS OF RECENT RESEARCH}

The categories of legal personality, passive legal capacity and active legal capacity; transactions, in particular, concluded by children and minors, their legal consequences; informatization of society and features that arise when concluding transactions by children and minors (including transactions via the internet); legal consequences of concluding transactions by children and minors outside their civil active capacity (under current legislation) with the use of information technology, in particular, and protection of the rights of participants in civil relations were investigated by scholars in different scientific works.

The works of such Ukrainian scholars are devoted to the study of the category of legal personality, including the legal personality of children and minors Volkova (2008), Gorbas (2008), Derbakova (2014), Karpenko (2001), Logvinova (2006), Remenyak (2007), and Chorna (2005).

Thus, Volkova (2008) devoted her dissertation research to the definition of civil law means of individualization of persons, their features and types, as well as the relationship between the legal personality of persons 
and its individualizing features. Besides, Gorbas (2008) analyzed the theoretical and practical aspects of the exercise of civil rights of individuals, namely, explored the concept of the exercise of civil rights of individuals, ways, limits of the exercise of civil rights of individuals, abuse of rights.

Derbakova (2014) researched the general theoretical principles of the legal personality of minors and proved that the legal personality of minors should include passive legal capacity and active legal capacity, co-legal capacity, and argued that not all powers of a minor can be realized through a mechanism of co-legal capacity. Also, Derbakova analyzed some civil legal relations and the legal status of minors, as well as considered the mechanism of assistance in the realization of the rights of minors, which is included in the legal personality of minors and which determines its specificity. Furthermore, Karpenko (2001) studied the problems of legal support and upbringing of orphans and children deprived of parental care in Ukraine, for which she considered the historical experience of Ukraine and modern foreign practice in addressing this issue, as well as analyzed the legal framework in this area. As a result, the current boarding school system is inconsistent with the norms of the United Nations Convention on the Rights of the Child and the interests and needs of minors in Ukraine in various areas.

Logvinova (2006) studied the legal relations of civil and family-legal responsibility of parents (persons who replace them) for offenses committed by minors and provided suggestions for improving the legal regulation of these relations. Moreover, Remenyak (2007) explored the theoretical basis of obligations arising from harm to minors, including paying considerable attention to the general characteristics of obligations arising from harm to minors, determining their place in the system of obligations, as well as analyzed features of the subjects of obligations arising from the infliction of damage, as well as the specifics of the grounds (conditions) for their occurrence. In addition, Chorna (2005) analyzes civil-legal methods of protection of property rights of minors, in particular, systematizes the classification of methods of protection of property rights of individuals. She identifies problems related to the protection of property rights and interests of minors. She insists on the need to clarify age criteria, according to which the scope of active legal capacity of children is determined and the necessary conditions for the adoption of a single normative act, which would regulate the rights of children and minors, are identified.

Attention should be paid to the research of leading scholars, which were carried out in the form of scientific articles on this topic. In particular, these are the works of Biryukov and Zaika (2006), Vodopyan (2013), Zaika (2005), Reznik (n.d.), Romovska (1995, 2013), Formanyuk (2007, 2013), Kharytonov E., Kharytonova O., and Startsev A. (2010). 
Considerable attention has been paid to the study of the transaction and its invalidity in the scientific literature. We analyzed the works that partially studied the issues of the commission of transactions by children and minors and the consequences of such commission (the validity of the transaction or its invalidity). Thus, Bobko (2011) analyzes the concept of "transaction", its formation in the civil legislation of Ukraine, examines the consequences of the transaction, as well as the requirements of the law to the content and form of the transaction, etc. Further, Bakhayeva (2018) considers several problems that arise in the new business environment, weakening control over the economic activities of civil society, low level of legal awareness of society, and contribute to the growing number of transactions concluded in violation of basic legal requirements. Special attention is paid to the need to improve the provisions on the application to the parties of an invalid transaction, which was committed under the influence of deception and violence of the rules on the protection of property rights. Dlugosh (2013) thoroughly investigated the invalidity of transactions with defects of will, noting the difference between transactions in which the participant's will is formed incorrectly (for example, transactions committed under the influence of error, deception, difficult circumstances, and extremely unfavorable conditions) and transactions committed without the participant's will (for example, transactions committed under the influence of violence, as a result of a malicious agreement between a representative of one party and the other party).

Moreover, Davydova $(2011,2018)$ examines transactions and their invalidity, the transformation of transactions in the information society, the impact of technological progress on transactions, including transactions with the participation of minors. Ivanova (2014) studied the legal nature of invalidation of a transaction as a way to protect civil rights and interests and apply the consequences of its invalidity in their systemic characteristics. Kucher (2004), in his works, pays attention to the analysis of the legal nature of insignificant transactions, their classification, as well as the differences between insignificant and unconcluded transactions, analysis of types of insignificant transactions on the grounds of their invalidity. Besides, Mishchenko (2014, 2015a, 2015b) analyzes the procedure of committing transactions by minors, which is beyond their active legal capacity. He also considers the consequences of such an act, and the types of transactions involving minors, distinguishing those that may be committed by minors personally, or which are committed in their favor. Moreover, he studies the institution of the active legal capacity of individuals and the ratio of the partial and not full active legal capacity of individuals. As well as, Semushina (2010) examines the legal nature of invalid transactions 
(including invalid transactions committed as a result of the violation of the condition of validity), features of legal regulation of relations arising from the commission of invalid transactions, characterizes the consequences of invalidation of transactions (analyzes the general, additional and special consequences of invalidity of transactions). However, in the works of mentioned scholars, transactions involving children and minors are not comprehensively studied.

The demands of the time prompted the need to introduce such a form of transaction as an electronic transaction. E-commerce is the subject of research by the following scholars Baranov (2010), Bachynskyi (2014), Blazhivska (2014), Volynets (2016), Golubeva (2017), Davydova (2018), Kizlova (2017), Filatova (2017), Garasimov (2016). Listed scholars reveal the concept of e-commerce, the procedure for concluding contracts in electronic form, identification of participants, features of access to personal data, etc., analyze both current civil law on this issue and foreign experience, both theoretical issues and practical aspects. The most comprehensive is the study of electronic transactions, conducted by Blazhivska (2014), who analyzed the concept, nature, procedure, and the possibility of invalidation and features of certain types of electronic transactions. At the same time, these works do not pay attention to the electronic transactions committed by children and minors.

The study of the categories "information society", "IT law", "information technology" as factors in the formation of the information society and a new understanding of transactions and their invalidity, is the subject of some scientific attention. A number of the works are devoted to the study of the aspects of the formation of the information society, namely Aristova (2002), Baranov (2015), Belyakov (2009), Kalyuzhnyi and Novitskaya (2006), Lipkan and Zaliznyak (2012), Savinova (2012).

In the field of private (in particular, civil) law, we can note the doctoral dissertation research of Kokhanovska (2006) and Kodynets (2016), who paid attention to the study of civil-legal issues of information and binding information relations in Ukraine. Kokhanovska (2006) studied the concept and civil law regulation of information relations; civil-legal problems of realization and protection of information rights; determined the place of information legal relations in the system of law and legislation of Ukraine, as well as the concept of information civil-legal relations; features of realization of information rights in the sphere of personal non-property legal relations, intellectual property legal relations and legal relations of property; basic civil legal methods of protection of information rights; trends in the development of the information security system, taking into account civillegal protection methods. 
Moreover, Kodynets (2016) examined theoretical and practical problems of civil-legal regulation of obligatory information relations, paid attention to the analysis of problems of legal nature, system, and structure of obligatory information relations, as well as considered features of civil-legal regulation of agreements in the field of information relations, stated specifics of the participant's rights and interests protection in the civil-legal information relations.

The development and use of information technology, the formation of the information society indicates the need to present new concepts, categories, institutions that would ensure proper legal regulation, appropriate protection of the rights and interests of citizens in the new, digital age. Thus, the following scholar conducted the study of «IT law» Bachynskyi (2017), Davydova (2017), Kharytonov E. and Kharyonova, O. (2017), Yavorska (2017).

Among foreign authors who studied the stated issues, we should single out Natalie M. Banta with her article "Minors and digital assets succession" and Ryan Calo with his article "Digital market manipulation".

In particular, Natalie M. Banta (2019) claims, that despite the fact that minors have the capacity to contract with online businesses, make health care decisions, marry, have sex, and seek employment, minors are denied one of the most basic rights of property ownership-the right to devise. So, the author proposes to grant minors capacity to devise their digital assets.

In turn Ryan Calo's article (2014) updates the framework of the theory of market manipulation to account for the realities of a marketplace that is mediated by technology. The author analyzed the problems of manipulation in the digital market, in particular, in terms of participation of minors in relevant relationships.

At the same time, the peculiarities that arise when concluding transactions by children and minors, including via the internet, are explored insufficiently. In this context, there is a need to study the issue of protection of these persons from illegal or unfavorable for the child transactions committed under the influence of both traditional factors (deception, abuse, etc.) and special factors directly related to the use of technology (electronic transaction, identification of the person and confirmation of the capacity, etc.). All this indicates the need for further research in this area. And the real expansion of the range of transactions committed by children and minors leads to consideration of the issue of expanding their capacity and ensuring the security of transactions through the introduction of the latest technological solutions.

Moreover, considering that during the quarantine persons under the age of 14 were prohibited from staying in public places unaccompanied by 
parents, adoptive parents, guardians, trustees, foster parents, and other persons under the law or adult relatives of the child. It has also been found that people who have reached the age of 60 need self-isolation. Several questions arise in this context. For example, how is it possible to visit public places for a child, if a child under the age of 14 lives with a person over the age of 60 ?

\section{RESULTS AND DISCUSSION}

The legal personality of individuals includes passive legal capacity and active legal capacity. Given the fact that passive legal capacity (a person's ability to have civil rights and responsibilities (Civil Code of Ukraine, 2003)) arises from birth and ends with death, and the amount of passive legal capacity of an individual (the ability to acquire civil rights and exercise them, as well as the ability to create civil duties, perform them independently and be responsible in case of non-fulfillment (Civil Code of Ukraine, 2003)) depends on the onset of a certain age, it is logical for the legislator to establish one of the conditions of validity of any transactioncompliance of the person who performs it, the required amount of civil active legal capacity.

To have active legal capacity means to have the ability to personally perform various legal actions: enter into contracts, issue powers of attorney, etc., as well as be liable for property damage (damage or destruction of another's property, damage to health), failure to perform contractual and other obligations (Stavchina, 2013).

Given that a person must act independently, having a sufficient level of consciousness and will, the determining factor here is the age and mental state of the person. Thus, there are questions about the scope, types, and structure of legal capacity, as well as about clarifying its scope for certain categories of persons and granting full active legal capacity to minors (emancipation of minors) (Nadion, 2014).

Chorna (2016) correctly notes that civil active legal capacity involves a conscious and correct assessment of human actions and has legal significance. The maturity of the psyche depends on the age and mental health of the person. Therefore, in contrast to civil passive legal capacity, which is equal for all individuals, the equal amount of civil active legal capacity does not exist.

According to the law, children are partially capable and therefore can perform only a small range of actions within their active legal capacity, in particular, small household transactions. On the other hand, minors have the 
opportunity to perform a much wider range of transactions than children. However, minors have limited active legal capacity compared to persons who have reached the age of majority and obtained full active legal capacity.

Historically, children reached the age of majority at an earlier age than they do today. Under the early common law, children were much more engaged in civic life. They could marry at age seven, be hanged at age eight for committing a crime, and serve on a jury at age twelve. Children could vote if they owned property; teenagers were elected to Parliament. In the early common law of England, children were able to contract, own property, and devise personal property by the age of four (Banta, 2019).

The characteristics of a small household transaction, defined in the legislation ("household needs", "conformity of personal development", "low cost"), are quite evaluative and in each case may be interpreted differently. It is also important that a child commits small household transactions at the expense of money provided for these purposes by legal representatives. Quite often transactions are made in the presence of such a representative, which indicates the consent to the transaction. If it is a question of committing a transaction by a minor (for example, buying lunch at school, stationery, or the necessary products for the house), the money is provided by legal representatives in the required amount and for specific purposes, where, in most cases, the adult will see the result transaction.

A child may enter into transactions outside his/her active legal capacity with: (i) the else child who has partial active legal capacity; (ii) a minor who has not full active legal capacity; (iii) an emancipated minor who has acquired full active legal capacity and is equated to an adult; and, (iv) an adult who has full active legal capacity.

Each of these options will have its characteristics of the consequences of such transactions for the child who committed it (given that such transactions will not be approved by parents (adoptive parents) or one of them, with whom a child lives, or trustee and will not be recognized by the court as valid.

If the committed transaction is outside the civil active legal capacity of the child who committed it, but committed in his favor, then it may be recognized as valid in court at the request of the interested party. However, there may be a situation where there is no interested person who would sue for the recognition of the transaction as valid, which puts children in an unequal position, and the commission of similar transactions in their favor in one case will be recognized as a valid transaction, and not in another one.

Regarding the quarantine regime, restrictions on a person's right to travel, age restrictions on visiting public places, the following statements should be made. 
The analysis of the disease trend established that younger people are not a risk group (unlike the elderly). As for the commission by children of small household transactions in the conditions of Covid-19, which becomes impossible due to the ban to move independently (unaccompanied by adults), this situation is not appropriate. Given that if a child (whose age normally allows committing small household transactions, such as the purchase of food, hygiene products, etc.) lives only with elderly grandmother, grandfather (or elderly trustees) (who must be in selfisolation) - in the case of conscientious fulfillment of the provided restrictions - all of them can be left without food, medicines, etc. One of the ways out of this situation could be to ensure the possibility to purchase and delivery of goods by children online, payment for such goods, etc.

In these circumstances, we consider fair such restrictions for children as visiting educational institutions, parks, squares, recreation areas, forest parks, and coastal areas, in addition to walking pets by one person; visiting sports and children's playgrounds, etc. And even in the listed restrictions, there is a question concerning "walking pets", after all, in practice, there can be a situation when there is simply nobody except the child who remained at home to go out to walk a pet (parents can be at work) and according to the analyzed Resolution has no right to leave unaccompanied by adults, as a child is under 14 years old.

A minor has more opportunities to perform transactions independently (compared to a child), but several restrictions require the permission of legal representatives or the recognition of such a transaction as invalid. Analysis of the development of civil law, the information society gives grounds to say that "de facto" there is a wide range of opportunities for transactions by minors, due to the active use of technology, expanding earning opportunities (including online), and also caused by the motivation of the state to switch to the use of digital technologies. One of such services is the Diya portal, where people who have turned 14 are called "almost adults". This portal contains all the information on the possibility of obtaining a passport of a citizen of Ukraine and a passport for travel abroad, lists the general and family rights, provides information on civil liability and liability for crimes, etc.

This provides grounds for the two groups of minors (from fourteen to sixteen years and sixteen to eighteen years), which will allow within each group to determine the possibility of committing certain transactions depending on the participation of minors in specific personal non-property and specific property rights, taking into account the main mechanisms of directed socialization of the person. 
A feature that affects the formation of the moral sphere of the individual in virtual reality is the actual lack of binding of content to the moral laws, moral norms of human coexistence, due to anonymity and freedom from the restrictions of the internet environment. This is especially important for the use of such content by children and minors, because the internet, as a social institution, has several specific characteristics that determine the process of socialization of a person different from traditional social institutions (family, NGOs, educational and religious institutions, etc.). There is some negative impact on the individual and its formation (which is manifested in changes in the psyche, mental health, changes in values, life positions, landmarks, the worldview of the individual, etc.), resulting in a negative impact on public consciousness.

Elements of the possible negative impact of the internet on the behavior of children and minors is carried out by blogs, social networks, and internet societies, etc., which make a kind of psychological (moral) pressure due to the unformed psyche of the child, fear to be humiliated, ridiculed, etc. Of particular relevance were the problems:

- to overcome cyber-bullying (which can result in cyber suicide);

- free access to deviant information promoting antisocial behavior that may lead to illegal behavior of a minor; and,

- violation of personal non-property rights by teaching on telegram channels or free access to photos and videos of mental and physical violence of peers (beatings, photos of a provocative nature due to intoxication), etc.

As children spend more time in front of computer monitors, they typically spend less time in physical activities. The sedentary lifestyle associated with computer usage can be a prime risk factor for obesity, according to clinical psychologist Sawmy (n.d.), author of "The Impact of Internet Use on Children/Adolescents." Furthermore, computer use is linked to both repetitive motion injuries like carpal tunnel and eye strain. For some children, the rapidly flashing images of certain websites and games can trigger epileptic seizures, according to authors of "The Impact of Home Computer Use on Children's Activities and Development," published by Princeton University.

Children with easy access to the internet may become less able to separate fact from fiction. The internet has no filter and no peer review, so anyone can publish anything they want. Educators also worry that the informal communication common to chat rooms has carried over into academic settings. Students facing challenging homework tasks and essays are becoming more likely to plagiarize from internet sources. The multitasking that many children engage in while online reduces attention span, making intense concentration on a single task more difficult. 
Increased internet use among children may result in feelings of loneliness and depression, warns Sawmy (n.d.). However, more online time does result in less time spent with family and friends or working on hobbies. The rapid and instant nature of internet stimulation alters the way a young person sees the world, leading to more boredom with everyday life.

Desensitization to violent stimuli is one potential consequence of excessive internet usage in children, warns the City of Manchester Health Department. Both violent and pornographic imagery can fundamentally alter a developing child's perspective on the world.

Child pornography is especially disturbing and may forever change a child's understanding of human sexuality. The violent images, foul language and lack of social rules common to the internet do not prepare anyone, much less a growing child, for interaction in the real world.

Advertising, which can be observed when using the internet, has a great influence on the desire to make one or another transaction. Minors and children who have not yet formed a psyche, cannot reasonably separate the rational from the "information garbage" and want to "compete" with peers, somehow stand out, or simply "want what is in advertising", and, as a result, they try to make deals on which legal representatives would never agree to. In particular, in practice, there are cases of transactions committed by children for quite large sums (for example, disposal of funds given for a birthday), or the exchange (not authorized by legal representatives) of expensive, and which are invalid.

In particular, in accordance with Art. 221 of the Civil Code of Ukraine (2003) a transaction concluded by an infant beyond his/her civil capacity may be subsequently approved by his/her parents (adoptive parents) or by the one of them with whom the minor resides, or by a guardian. A transaction shall be considered approved, where these persons, having learned about its conclusion, do not file any claim against the other party within a month. In case of absence of such approval, the transaction shall be void.

Transactions can be made not only when using special websites of registered legal entities and individual entrepreneurs, but also when using social networks, the most common of which are now Facebook, YouTube, Twitter, Instagram, Telegram. Making transactions via social networks is quite common among children and minors, so there can be a lot of abuse (for example, misleading about the quality of goods; fraud in making an advance or subscription; conducting various kinds of challenges, which can result in violation personal non-property rights or harm to health, the inclination to use prohibited beverages, etc.; violation of the rules on the processing of personal data, etc.). 
The difficulty of ensuring the effectiveness of legal regulation of the internet is not only the lack of systematic or harmonized legislation to regulate the relationship, but also the objective features and patterns of the internet, which in fact "allow" anyone to do anything anonymously online. The de facto impossibility of legal prosecution of offenders on the internet (which is especially evident on the example of administrative and criminal liability) leads to unlimited freedom of action, which can now be observed in cyberspace (Lesko, 2016). Therefore, it is necessary to expand the range of information and communication relations that should be subject to legal regulation. This applies to the problems of legal regulation of information circulation and communication on the internet, to which even preschool children have access.

In our opinion, the international experience in resolving the issue at the regulatory level is positive in this context, in particular, the adoption on December 3, 2009, by the Interparliamentary Assembly of the Commonwealth of Independent States member states of the Model Law "On Protection of Children from Information Harmful to Their Health and Development", which establishes the legal and organizational framework for state policy and international cooperation of the Commonwealth of Independent States member states in the field of information security of children, taking into account generally accepted principles and norms of international law, including those enshrined in the U.N. Convention on the Rights of the Child (1989).

There is a certain dependence of children on computer games and online entertainment. Surveys confirm the fact that about $75 \%$ of respondents (schoolchildren aged 8 to 14) spend $1 / 3$ of their free time on the internet (watching movies online, communicating on social networks, playing games online). Most online games are aimed at obtaining direct or "hidden" monetary income, which occurs, in particular, by transferring cash to certain accounts (using a bank card, mobile phone, payment terminal, electronic money, etc.), and the public offer is addressed to an unlimited number of persons, where age restrictions either do not exist or they are outlined only formally (actual control over their observance is not carried out) (Stefanchuk, 2016). Quite often children spend money earned on their own or received as a gift or for "pocket" expenses. There are also cases when people under the age of 14 are already working (film industry, circuses, etc.), and can also actually spend their salary freely. Therefore there is an expansion of the partial active legal capacity of children.

The expansion of the active legal capacity of both children and minors is evidenced by the draft Law of Ukraine $n^{\circ} 2684$ submitted to the Verkhovna Rada on December 27, 2019, which provides the notion of 
"adolescent" (a child aged 10 to 18); expanding the powers of a minor, in particular, by providing with: (i) the right to reliable and complete information about his health, including access to relevant medical documents relating to his health (previously in accordance with Part 1 of Article 285 of the Civil Code of Ukraine could have only an adult); and, (ii) the ability to independently enter into and perform transactions related to the provision of medical services.

However, this draft law does not provide for possible risks and abuses that may occur in the field of "provision of medical services", given the lack of requirement to obtain permission from the legal representatives of a minor for such services; there are no means to ensure the protection of the rights and interests of these persons.

Thus, on the one hand, the informatization of society has led to a situation in which the actual capacity of children and minors is wider than enshrined in law. At the same time, violations of rights and legitimate interests and abuses in the field of transactions by such persons are also much greater, which is caused, in particular, by the peculiarities of their commission on the internet:

- uncertainty of the parties' location;

- the uncertainty of the time of sending and receiving information materials;

- the reliability of the information obtained and the provability of the contract; the dependence of relations between network participants on relations with information providers;

- the electronic nature of document flow in the network, which necessitates the use of special software and hardware;

- conclusion of contracts by programs-robots without the participation of the person, etc.

Therefore, a comprehensive approach is needed. On the one handthe expansion of the capacity of children and minors (including clarification of age limits for each of these categories of persons), on the other-the use of technologies that would allow complying with the established restrictions on the commission of certain transactions, as objectively as possible covered information on the identification of a person, the expression of the will, provided an opportunity to protect the rights of children from violations. One such solution could be the use of blockchain technology, which is already used in many countries around the world and is becoming increasingly popular. A blockchain is a growing list of records, called blocks, that are linked using cryptography. Each block contains a cryptographic hash of the previous block, a timestamp, and transaction data (generally represented as a Merkle tree). By design, a blockchain is resistant to modification of the 
data. It is an open, distributed ledger that can record transactions between two parties efficiently and in a verifiable and permanent way.

The proposal of the use of blockchain and smart contracts in transactions (which is put forward in Ukraine by Davydova $(2018,2019)$ ) is useful because globalization involves the unification of all processes regardless of the country; society is formed as a holistic system that lives by common principles, rules, and norms.

\section{CONCLUSIONS}

1. The development of information technologies and their active introduction into our lives has influenced the possibility of commission of the transactions by children and minors, in particular, by expanding them. Therefore, the question arises as to the classification of transactions committed by a child to small household transactions, for example, if they are concluded via the internet. Electronic transactions are mostly recognized as written, and small household as oral (or implicit actions). However, ordering essential goods, in particular, food via online stores or delivery service is a small household transaction "essentially", but it is not an oral transaction.

2. Analysis of the category "minor domestic transactions" (which can be committed by both children and minors) makes it possible to identify such basic characteristics as: "domestic needs", "compliance with personal development", "low cost". Each of these categories should be interpreted separately for each situation. It is impossible to talk about uniform requirements (level) of "domestic needs" or "appropriateness of personal development" for a child of four, eight, twelve and sixteen years, just as the category of "low cost" is not universal and should be related to the income of a particular family. Therefore, in each case, the maximum allowable amount of cash equivalent of the transaction must be set separately. The list of "domestic needs" also directly depends on the development of society, and therefore over time expands. For example, today domestic needs include payment for the services of internet providers, mobile operators, purchase and payment for goods and services through online stores, etc. The participants to these transactions may be, in particular, children and minors. There is also a group of transactions that are not committed by children themselves, but in their favor (the children is the beneficiary). The transactions include:

- bank deposit agreement;

- insurance contract for the benefit of a third party; property management agreement; 
- real estate purchase and sale agreement;

- other types of transactions that are not provided by acts of civil legislation, but correspond to the general principles of civil legislation.

Such transactions can also be made using the newest technology, which necessitates the protection of the rights of beneficiaries.

3. Nowadays, a child has access to the internet even at the age of three and can actually (yet accidentally) perform certain actions that will be considered a transaction (for example, the purchase of some reinforcements for a player in a computer game). In this case, it may be a mistake and the need for restitution. However, from the age of five or six, a person can make purchases on the internet and understand the result of their actions (though still at the level of "I want this toy", etc.), which may not coincide with the desire of legal representatives to buy this thing for such a price. Other situations are when a child starts buying something in the store for "pocket" money (for example, instead of lunch in the school canteen, the child may buy not good for health sweets, carbonated drinks, etc. in the store). Thus, the range of transactions that children can make following the law, in practice is constantly expanding, which is associated, in particular, with the development of society, information technology, "growing up" of children under 14 years of age.

4. This issue should be clarified at the legislative level. In particular, it is proposed to consolidate the division of minors into the following groups: from 0 to 6 years (have a right for minor ordinary transactions); from 6 to 10 years (have a right for minor ordinary transactions and limited range of transactions in the internet); from 10 to 14 years (have a right for minor ordinary transactions, increased range of transactions in the internet, increased range of rights in the family legal relations). The difficulty of ensuring the effectiveness of legal regulation of the internet is not only the lack of systematic or harmonized legislation to regulate the relationship, but also the objective features and patterns of the internet, which in fact "allow" anyone to do anything anonymously online, where each of the groups will have its own powers and the ability to perform certain transactions in order to meet the domestic needs of the person (according to the age of the person) and which will meet the physical, spiritual or social development (again within appropriate age category).

5. The use of technologies such as blockchain and programs such as smart contracts, which are already used in many countries around the world and are becoming increasingly popular, is necessary to organize transactions and ensure clear implementation of agreements between parties, compliance with legal requirements for validity, etc. 


\section{REFERENCES}

Aristova, I.V. (2002). State information policy and its implementation in the activities of law enforcement agencies: organizational and legal principles. Kharkiv: National Academy of Internal Affairs of Ukraine. In http://dspace.univd.edu.ua/xmlui/handle/123456789/2348.

Bachynskyi, T. V. (2014). Some novelties of legislative regulation of e-commerce in Ukraine. Scientific notes of Lviv University of Business and Law, 12, 168-171. In http://www.irbis-nbuv.gov.ua/cgibin/irbis_nbuv/cgiirbis_64.exe?I21DBN=LINK\&P21DBN=UJRN\&Z21ID=\&S $21 \mathrm{REF}=10 \& \mathrm{~S} 21 \mathrm{CNR}=20 \& \mathrm{~S} 21 \mathrm{STN}=1 \& \mathrm{~S} 21 \mathrm{FMT}=\mathrm{ASP} \_$meta $\& \mathrm{C} 21 \mathrm{COM}=\mathrm{S} \& 2$ _S21P03=FILA=\&2_S21STR=Nzlubp_2014_12_40.

Bachynskyi, T. V. (2017). Fundamentals of IT law. Kyiv: Jurinkom Inter.

Bakhayeva, A. S. (2018). Invalidity of transactions committed under the influence of deception and violence. Kharkiv: Kharkiv National University of Internal Affairs. In http://dspace.univd.edu.ua/xmlui/handle/123456789/5029.

Banta, N. M. (2019). Minors and digital asset succession. Iowa Law Review, 104(4), 1699-1746.

Baranov, O. A. (2010). To the problem of electronic transactions. Legal informatics, 4, 3-

8. In http://ippi.org.ua/oa-baranov-do-problemi-elektronnikh-pravochiniv.

Baranov, O. A. (2015). Theoretical and methodological foundations of legal support of the information sphere of Ukraine. Kharkiv: National Academy of Internal Affairs of Ukraine. In http://dspace.univd.edu.ua/xmlui/handle/123456789/2348.

Belyakov, K. I. (2009). Organizational, legal and scientific support of information in Ukraine: problems of theory and practice. Kyiv: Alerta.

Biryukov, I. A., Zaika, Y.O. (2006). Civil law of Ukraine. General part. Kyiv: KNT. In http://www.info-library.com.ua/books-book-166.html.

Blazhivska, N.E. (2014). Electronic transaction in the civil law of Ukraine. Kyiv: Alerta.

Bobko, T. V. (2011). The content and form of the transaction in civil law. Kharkiv: National Law Academy of Yaroslav the Wise. In http://www.irbisnbuv.gov.ua/cgibin/irbis_nbuv/cgiirbis_64.exe?C21COM=S\&I21DBN=EC\&P21DBN=EC\&S2 1FMT=JwU_B\&S21ALL=\%28\%3C.\%3EU\%3D\%D0\%A5839\%284\%D0\%A3 $\%$ D0\%9A\%D0\%A0\%29041\$\%3C.\%3E\%29\&Z21ID=\&S21SRW=AVHEAD $\& \mathrm{~S} 21 \mathrm{SRD}=\& \mathrm{~S} 21 \mathrm{STN}=1 \& \mathrm{~S} 21 \mathrm{REF}=10 \& \mathrm{~S} 21 \mathrm{CNR}=20$.

Calo, R. (2014). Digital market manipulation. George Washington Law Review, 82(4), 995-1051.

Chorna, J. L. (2005). Civil law protection of property rights and interests of minors. Odesa: Phoenix. In http://irbis-nbuv.gov.ua/cgibin/irbis_nbuv/cgiirbis_64.exe?Z21ID=\&I21DBN=ARD\&P21DBN=ARD\&S2 
$1 \mathrm{STN}=1 \& \mathrm{~S} 21 \mathrm{REF}=10 \& \mathrm{~S} 21 \mathrm{FMT}=$ fullwebr $\& \mathrm{C} 21 \mathrm{COM}=\mathrm{S} \& \mathrm{~S} 21 \mathrm{CNR}=20 \& \mathrm{~S} 21$

$\mathrm{P} 01=0 \& \mathrm{~S} 21 \mathrm{P} 02=0 \& \mathrm{~S} 21 \mathrm{P} 03=\mathrm{A}=\& \mathrm{~S} 21 \mathrm{COLORTERMS}=1 \& \mathrm{~S} 21 \mathrm{STR}=\% \mathrm{D} 0 \% \mathrm{~A}$ 7\%D0\%BE\%D1\%80\%D0\%BD\%D0\%B0\%20\%D0\%96.\%D0\%9B.\$.

Chorna, J. L. (2016). The commission of a transaction by a minor outside his civil capacity as a ground for its invalidity. University scientific notes, 57, 110-117. In http://www.irbis-nbuv.gov.ua/cgibin/irbis_nbuv/cgiirbis_64.exe?I21DBN=LINK\&P21DBN=UJRN\&Z21ID=\&S $21 \mathrm{REF}=10 \& \mathrm{~S} 21 \mathrm{CNR}=20 \& \mathrm{~S} 21 \mathrm{STN}=1 \& \mathrm{~S} 21 \mathrm{FMT}=\mathrm{ASP} \_$meta\&C21COM=S $\& 2$ _S21P03=FILA=\&2_S21STR=Unzap_2016_1_12.

Convention on the Rights of the Child. (1989). General Assembly. In https://www.ohchr.org/en/professionalinterest/pages/crc.aspx.

Davydova, I. V. (2011). Invalidity of transactions concluded as a result of error and fraud. Odesa: Phoenix. In http://dspace.onua.edu.ua/handle/11300/1150?show=full\&locale-attribute=en .

Davydova, I. V. (2017). Laws in the IT field and information security. IT law and information security. Odesa: Phoenix, 74-86. In https://jurkniga.ua/wadata/public/shop/products/36/01/10136/attachments/\%D0\%86\%D0\%A2$\% \mathrm{D} 0 \% \mathrm{BF} \% \mathrm{D} 1 \% 80 \% \mathrm{D} 0 \% \mathrm{~B} 0 \% \mathrm{D} 0 \% \mathrm{~B} 2 \% \mathrm{D} 0 \% \mathrm{BE} \% 20 \% \mathrm{D} 1 \% 82 \% \mathrm{D} 0 \% \mathrm{~B} 0 \% 20$ $\% \mathrm{D} 1 \% 96 \% \mathrm{D} 0 \% \mathrm{BD} \% \mathrm{D} 1 \% 84 \% \mathrm{D} 0 \% \mathrm{BE} \% \mathrm{D} 1 \% 80 \% \mathrm{D} 0 \% \mathrm{BC} \% \mathrm{D} 0 \% \mathrm{~B} 0 \% \mathrm{D} 1 \% 8$ $6 \% \mathrm{D} 1 \% 96 \% \mathrm{D} 0 \% \mathrm{~B} 9 \% \mathrm{D} 0 \% \mathrm{BD} \% \mathrm{D} 0 \% \mathrm{~B} 0 \% 20 \% \mathrm{D} 0 \% \mathrm{~B} 1 \% \mathrm{D} 0 \% \mathrm{~B} 5 \% \mathrm{D} 0 \% \mathrm{~B} 7 \%$ D0\%BF\%D0\%B5\%D0\%BA\%D0\%B0.pdf.

Davydova, I. V. (2018). Blockchain and transaction category. Actual problems of civilization in the digital age. Odessa: Legal Literature.

Davydova, I. V. (2018). Deeds in an information society: prospects for development. Visegrad Journal on Human Rights, 2(2), 47-51.

Davydova, I. V. (2018). Transactions and their invalidity in the information society. Odesa: Phoenix. http://dspace.onua.edu.ua/handle/11300/10727.

Davydova, I. V. (2019). Blockchain and smart contracts: the future of information society transactions. Transcarpathian legal readings, 42-49.

Derbakova, Yu. A. (2014). Civil legal personality of minors. Odesa: Phoenix. In http://dspace.onua.edu.ua/handle/11300/1852.

Dlugosh, O.I. (2013). Invalidity of transactions with defects of will. Kyiv: Research Institute of Private Law and Entrepreneurship. In https://www.twirpx.com/file/1924601/.

Filatova, N. Yu. (2017). Transactions using an electronic form of information presentation. Problems of legality, 136, 40-55. In http://www.irbisnbuv.gov.ua/cgi-

bin/irbis_nbuv/cgiirbis_64.exe?I21DBN=LINK\&P21DBN=UJRN\&Z21ID=\&S $21 \mathrm{REF}=10 \& \mathrm{~S} 21 \mathrm{CNR}=20 \& \mathrm{~S} 21 \mathrm{STN}=1 \& \mathrm{~S} 21 \mathrm{FMT}=\mathrm{ASP} \_$meta\&C21COM=S\&2 _S21P03=FILA=\&2_S21STR=Pz_2017_136_7.

Formanyuk, V. I. (2007). Legal nature of the category "civil legal personality”. Legal life of modern Ukraine, 2, 254-255. 
Formanyuk, V. I. (2013). Age and condition of legal personality. Journal of Civil law, 14, 55-58. In http://www.irbis-nbuv.gov.ua/cgibin/irbis_nbuv/cgiirbis_64.exe?I21DBN=LINK\&P21DBN=UJRN\&Z21ID=\&S $21 \mathrm{REF}=10 \& \mathrm{~S} 21 \mathrm{CNR}=20 \& \mathrm{~S} 21 \mathrm{STN}=1 \& \mathrm{~S} 21 \mathrm{FMT}=\mathrm{ASP} \_$meta\&C21COM=S $\& 2$ _S21P03=FILA=\&2_S21STR=Chac_2013_14_12.

Garasimov, T. Z. (2016). Regulation of personal behavior in a virtual environment. IT law: problems and prospects of development in Ukraine, 5, 167-169.

Golubeva, N. Yu. (2017). E-commerce. IT law: theory and practice. Odesa: Phoenix.

Gorbas, D. V. (2009). Exercise of subjective civil rights of individuals: concepts, methods, boundaries. Kyiv: KNT. In http://www.disslib.org/zdiysnennja-subyektyvnykh-tsyvilnykh-prav-fizychnykh-osib-ponjattja-sposoby-mezhi.html.

Ivanova, S. M. (2014). Recognition of invalid transaction as a way to protect civil rights and interests under the laws of Ukraine. Kyiv: KNT.

Kalyuzhnyi, R. A., \& Novitskaya, N.B. (2006). Formation of the information society. Legal informatics, 3(11), 17-22.

Karpenko, O. I. (2002). Legal principles of maintenance and upbringing of orphans and children deprived of parental care. Kyiv: KNT.

Kharytonov, E. O., Kharytonova E. I., \& Startsev, A.V. (2010). Civil law of Ukraine. Kharkiv, Odysei. In http://irbis-nbuv.gov.ua/cgibin/irbis_nbuv/cgiirbis_64.exe?Z21ID=\&I21DBN=EC\&P21DBN=EC\&S21ST $\mathrm{N}=1 \& \mathrm{~S} 21 \mathrm{REF}=10 \& \mathrm{~S} 21 \mathrm{FMT}=$ fullwebr $\& \mathrm{C} 21 \mathrm{COM}=\mathrm{S} \& \mathrm{~S} 21 \mathrm{CNR}=20 \& \mathrm{~S} 21 \mathrm{P} 01$ $=0 \& \mathrm{~S} 21 \mathrm{P} 02=0 \& \mathrm{~S} 21 \mathrm{P} 03=\mathrm{A}=\& \mathrm{~S} 21 \mathrm{COLORTERMS}=1 \& \mathrm{~S} 21 \mathrm{STR}=\% \mathrm{D} 0 \% \mathrm{~A} 5 \%$ D0\%B0\%D1\%80\%D0\%B8\%D1\%82\%D0\%BE\%D0\%BD\%D0\%BE\%D0\%B2 $\% 20 \% \mathrm{D} 0 \% 95 \$$.

Kharytonova, O. I., \& Kharytonov, E. O. (Eds). (2017). IT-law: concept and essence. Odesa: Phoenix.

Kizlova, O. S. (2017). Electronic contract. Some types of agreements in modern Ukrainian legislation. Odesa: AisPrint.

Kodynets, A. A. (2016). Civil law regulation of binding information relations: methodology, theory, practice. Kyiv: Taras Shevchenko National University of Kyiv. In

http://www.library.univ.kiev.ua/ukr/elcat/new/detail.php3?doc_id=1740685\&au thor=\%EA\%EE\%E4\%E8\%ED\%E5\%F6\%FC\&div=0\&source=1\&prev=25\&pa ge $=0 \&$ doc Type $=24 \&$ doc Type $1=8 \&$ doc Type $2=17 \&$ doc Type $3=13 \&$ docType $4=$ 14\&docType $=15 \&$ docType6=26\&docType $7=18 \&$ docType $8=19 \&$ docType $9=$ $25 \&$ parentId $=0 \&$ sort $=1$.

Kokhanovska, O. V. (2006). Civil law problems of information relations in Ukraine.

Kyiv: KNT. In http://www.disslib.org/tsyvilno-pravovi-problemyinformatsiynykh-vidnosyn-v-ukrayini.html.

Kucher, V. O. (2004). Void transactions. Kyiv: National Academy of Internal Affairs of Ukraine. In http://194.44.11.130/cgi-

bin/irbis_nbuv/cgiirbis_64.exe?Z21ID=\&I21DBN=EC\&P21DBN=RUBS\&S21 
$\mathrm{STN}=1 \& \mathrm{~S} 21 \mathrm{REF}=10 \& \mathrm{~S} 21 \mathrm{FMT}=\mathrm{Jw} U \_\mathrm{B} \& \mathrm{C} 21 \mathrm{COM}=\mathrm{S} \& \mathrm{~S} 21 \mathrm{CNR}=20 \& \mathrm{~S} 21 \mathrm{P} 0$ $1=0 \& \mathrm{~S} 21 \mathrm{P} 02=0 \& \mathrm{~S} 21 \mathrm{P} 03=\mathrm{U}=\& \mathrm{~S} 21 \mathrm{COLORTERMS}=0 \& \mathrm{~S} 21 \mathrm{STR}=\% \mathrm{D} 0 \% \mathrm{~A} 58$ $39 \% 284 \% \mathrm{D} 0 \% \mathrm{~A} 3 \% \mathrm{D} 0 \% 9 \mathrm{~A} \% \mathrm{D} 0 \% \mathrm{~A} 0 \% 29043 \$$.

Lesko, N. V. (2016). Problems of information security of children on the Internet. IT law: problems and prospects of development in Ukraine, 5, 223-229.

Lipkan, V. A., \& Zaliznyak V.A. (2012). Systematization of information legislation of Ukraine. Kyiv: Lipkan Publishing House.

Logvinova, M. V. (2009). Civil and family law liability of parents for offenses committed by minors. Ivano-Frankivsk: Carpathian National University named after V. Stefanik. In http://irbis-nbuv.gov.ua/ulib/item/UKR0008170.

Mishchenko, M. V. (2014). The amount of partial and incomplete civil capacity of individuals. Scientific Bulletin of Kherson State University, 4(1), 138-142.

Mishchenko, M. V. (2015a). Committing transactions by children outside their active civil legal capacity. Scientific Bulletin of Kherson State University, 4(1), 114-117. In http://www.irbis-nbuv.gov.ua/cgi-

bin/irbis_nbuv/cgiirbis_64.exe?I21DBN=LINK\&P21DBN=UJRN\&Z21ID=\&S $21 \mathrm{REF}=10 \& \mathrm{~S} 21 \mathrm{CNR}=20 \& \mathrm{~S} 21 \mathrm{STN}=1 \& \mathrm{~S} 21 \mathrm{FMT}=\mathrm{ASP} \_$meta\&C21COM=S\&2 _S21P03=FILA=\&2_S21STR=Nvkhdu_jur_2015_4(1)_28.

Mishchenko, M. V. (2015b). Characteristics and types of transactions involving minors. Scientific Bulletin of Uzhhorod National University, 33(1), 138-141. In http://www.irbis-nbuv.gov.ua/cgibin/irbis_nbuv/cgiirbis_64.exe?I21DBN=LINK\&P21DBN=UJRN\&Z21ID=\&S $21 \mathrm{REF}=10 \& \mathrm{~S} 21 \mathrm{CNR}=20 \& \mathrm{~S} 21 \mathrm{STN}=1 \& \mathrm{~S} 21 \mathrm{FMT}=\mathrm{ASP} \_$meta $\& \mathrm{C} 21 \mathrm{COM}=\mathrm{S} \& 2$ _S21P03=FILA=\&2_S21STR=nvuzhpr_2015_33(1)_35.

Nadion, V. V. (2014). The structure of legal personality. Modern problems of civilization, 49-53. http://dspace.nlu.edu.ua/handle/123456789/5743?locale=en.

Remenyak, S. Ya. (2007). Compensation for damage caused to minors under the civil legislation of Ukraine. Odesa: Phoenix. In http://www.disslib.org/vidshkoduvannja-shkody-zavdanoyi-malolitnimyosobamy-za-tsyvilnym-zakonodavstvom.html.

Reznik, G. (n.d.). The concept and scope of legal capacity of minors in Ukraine and abroad. Pravnyk. In http://www.pravnuk.info/urukrain/1123-ponyattya-taobsyagdiyezdatnosti-nepovnolitnix-osib-v-ukrani-tazarubizhnix-kranax.html.

Romovska, Z. V. (1995). Civil capacity of a citizen (individual). Law of Ukraine, 2, 5154.

Romovska, Z.V. (2013). Ukrainian civil law. General part. Kyiv: Legal unity “Alerta”.

Savinova, N. A. (2012). Criminal law policy and security of the information society. Kyiv: Law of Ukraine. In http://ippi.org.ua/kriminalno-pravova-politika-taubezpechennya-informatsiinogo-suspilstva-v-ukraini.

Sawmy, K. G. (n.d.). The Impact of Internet Use on Children/Adolescents. In http://www.govmu.org/portal/sites/sid2011/files/Miss\%20Sawmy.pdf 
Semushina, O. V. (2010). Invalid transactions and legal consequences of their invalidity. Kyiv: University of State and Law named after V.M. Koretskyi. In http://www.irbis-nbuv.gov.ua/cgibin/irbis_low/cgiirbis_64.exe?Z21ID=\&I21DBN=EC\&P21DBN=EC\&R21DB $\mathrm{N}=1 \& \mathrm{R} 21 \mathrm{DBN}=2 \& \mathrm{~S} 21 \mathrm{STN}=1 \& \mathrm{~S} 21 \mathrm{REF}=10 \& \mathrm{~S} 21 \mathrm{FMT}=$ fullwebr $\& \mathrm{C} 21 \mathrm{COM}=$ $\mathrm{S} \& \mathrm{~S} 21 \mathrm{CNR}=20 \& \mathrm{~S} 21 \mathrm{P} 01=0 \& \mathrm{~S} 21 \mathrm{P} 02=0 \& \mathrm{~S} 21 \mathrm{P} 03=\mathrm{U}=\& \mathrm{~S} 21 \mathrm{COLORTERMS}=$ 0\&S21STR=\%D0\%A5839\%284\%D0\%A3\%D0\%9A\%D0\%A0\%2904\% 24 .

Stavchina, I. M. (2013). Legal personality of participants as an objective condition for the validity of a civil contract. Current problems of improving the current legislation of Ukraine, 31, 188-199. In http://www.irbis-nbuv.gov.ua/cgibin/irbis_nbuv/cgiirbis_64.exe?I21DBN=LINK\&P21DBN=UJRN\&Z21ID=\&S $21 \mathrm{REF}=10 \& \mathrm{~S} 21 \mathrm{CNR}=20 \& \mathrm{~S} 21 \mathrm{STN}=1 \& \mathrm{~S} 21 \mathrm{FMT}=\mathrm{ASP} \_$meta $\& \mathrm{C} 21 \mathrm{COM}=\mathrm{S} \& 2$ _S21P03=FILA=\&2_S21STR=apvchzu_2013_31_21.

Stefanchuk, M. O. (2016). On the question of the content of partial legal capacity in the civil law of Ukraine. Eurasian Academic Research Journal, 5, 46-55.

Ukraine. (2003). Civil Code. In https://zakon.rada.gov.ua/laws/show/435-15.

Ukraine. (2009). On the protection of children from information that harms their health and development: Law. In https://zakon.rada.gov.ua/laws/show/997_m85\#Text.

Ukraine. Draft Law on Amendments to Certain Legislative Acts Concerning the Realization of the Rights of Adolescents in the Sphere of Health Care No 2684. (2019). In http://w1.c1.rada.gov.ua/pls/zweb2/webproc4_1?pf3511=67795.

Vodopyan, T. V. (2013). Features of the legal capacity of minors in the civil law of Ukraine. Journal of the National University “Ostroh Academy”, 2(8), 1-13. In http://lj.oa.edu.ua/articles/2013/n2/13vtvtpu.pdf.

Volkova, N. V. (2008). Civil law means of individualization of individuals. Odesa:

Phoenix. In http://dspace.onua.edu.ua/handle/11300/1109.

Volynets, T. V. (2016). Legal regulation of electronic transactions. European perspectives, 1, 152-156. In http://www.irbis-nbuv.gov.ua/cgibin/irbis_nbuv/cgiirbis_64.exe?I21DBN=LINK\&P21DBN=UJRN\&Z21ID=\&S $21 \mathrm{REF}=10 \& \mathrm{~S} 21 \mathrm{CNR}=20 \& \mathrm{~S} 21 \mathrm{STN}=1 \& \mathrm{~S} 21 \mathrm{FMT}=\mathrm{ASP} \_$meta\&C21COM=S\&2 _S21P03=FILA=\&2_S21STR=evpe_2016_1_25.

Yavorska, L. S. (Eds). (2017). IT-law. Lviv: Levada.

Zaika, Y. O. (2005). Ukrainian civil law. Kyiv: Istyna. In http://194.44.152.155/elib/local/sk700610.pdf. 